Огляди літератури, оригінальні дослідження, погляд на проблему, ювілеї

УДК 616.69-008.8:616155.32-02.616.-002-055.1

DOI 10.11603/1811-2471.2018.v0.i2.8917

\title{
ВИВЧЕННЯ ДИНАМІКИ РІВНІВ CD4+CD25+, CD4+HLA-DR4+ TA CD4+CD95+ ЛІМФОЦИТІВ СПЕРМИ ІНФЕРТИЛЬНИХ ЧОЛОВІКІВ З ХРОНІЧНИМ ЗАПАЛЕННЯМ УРОГЕНІТАЛЬНОГО ТРАКТУ ПІД ВПЛИВОМ НУКЛЕКСУ
}

\author{
๑С. Ю. Ціпоренко, Л. Ф. Матюха \\ Національна медична академія післядипломної освіти імені П. Л. Шупика
}

РЕЗЮМЕ. Вступ. У практиці сімейних лікарів почастішали випадки звернень чоловіків із порушенням запліднювальної функції. Ретельний збір анамнезу дозволяє запідозрити, що зниження фертильності у чоловіків супроводжується латентним та персистуючим перебігом урогенітальних інфекцій, що дуже ускладнює їх своєчасну діагностику.

Мета - дослідження маркерів активації лімфоцитів сперми чоловіків з малосимптомними формами хронічної інфекції урогенітального тракту в залежності від фертильності та впливу нуклексу на їх рівні.

Матеріал і методи. Було досліджено сперму 60 чоловіків, хворих на малосимптомні форми хронічного запалення урогенітального тракту (ХЗУТ); І групу склали 32 пацієнти, в яких діагностували ускладнення - інфертильність, у II групу ввійшли 28 фертильних пацієнтів.

Висновки. 1. Вивчення маркерів активації лімфоцитів сперми у чоловіків, хворих на малосимптомні форми хронічної інфекції урогенітального тракту, вказує на різнопланове збільшення їх кількості залежно від фертильності.

2. Діагностично важливим $\epsilon$ визначення співвідношення CD25+/CD95+ для прогнозування розвитку інфертильності. 36ільшення цього індексу вказує на порушення процесів апоптозу патологічних форм генеративних клітин, що призводить до їх накопичення у спермі.

3. Імунокорегуюча терапія з використанням нуклексу приводить до нормалізації співвідношення CD25+/CD95+, до зменшення патологічних форм сперматозоїдів й, зрештою, до збільшення запліднювального потенціалу.

КлючовІ СловА: чоловіче безпліддя; сперма; маркери активації лімфоцитів; імунокорекція; нуклекс.

Вступ. У практиці сімейних лікарів почастішали випадки звернень чоловіків із порушенням запліднювальної функції. Ретельний збір анамнезу дозволяє запідозрити, що зниження фертильності у чоловіків супроводжується латентним та персистуючим перебігом урогенітальних інфекцій, що дуже ускладнює їх своєчасну діагностику. Водночас статеві бактеріально-вірусні інфекції часто залишаються нерозпізнаними, оскільки мають мізерну клінічну симптоматику або взагалі її не мають, й тому уражені чоловіки не звертаються за медичною допомогою, тоді як патологія прогресує і часто ускладнюється розвитком інфертильності.

Чоловіча сперма містить не лише сперматозоїди, а й популяції несперматозоїдних клітин, переважно це лейкоцити. Існують суперечки щодо біологічної ролі лейкоцитів у спермі. Деякі дослідники вказують на недостаній зв'язок між наявністю лейкоцитів та якістю сперми чи інфертильним статусом і роблять припущення щодо позитивної ролі цих клітин у видаленні мертвих клітин чи пошкоджених сперматозоїдів. Однак більшість авторів стверджують про наявність тісного зв'язку між збільшеною кількістю лейкоцитів у спермі та погіршенням її властивостей або запліднювальної здатності, головним чином - зниження рухливості сперматозоїдів або їх потенціалу до пенетраціїі ооцитів. Припускають, що знижена запліднювальна можливість сперми $\epsilon$ на- слідком впливу лейкоцитоспермії, асоційованої 3 інфекцією сечостатевого тракту. Ряд досліджень виявили збільшення кількості CD25+лімфоцитів у спермі на тлі незмінної кількості частки клітин CD95+, що було проявом збільшення пропорції CD25+/CD95+. Як показало дослідження, збільшення цього індексу, як і його зниження, було асоційоване з безпліддям. Це дало змогу припустити, що пригнічення апоптозу активованих лімфоцитів в еякуляті потенційно небезпечне для сперматогенезу, оскільки імунна відповідь та пов'язані з нею запальні реакції можуть викликати неспецифічне пошкодження оточуючих тканин та індукцію патоспермії. Це пошкодження може бути спричинене хронічним запальним процесом без клінічних проявів. Аналіз маркерів активації субпопуляцій імунокомпетентних клітин багато в чому визначає ефективність імунної відповіді. Оцінка активації лімфоцитів полягає у визначенні на їх поверхні активаційних маркерів CD25, HLA-DR4, CD95, їх експресія пов'язана з проходженням певного етапу клітинної диференціації. При захворюваннях, що супроводжуються тривалою антигенною дією та інтоксикацією, порушуються швидкість утворення і диференціювання лімфоцитів, інтенсивність апоптозу, що призводить до порушень в імунній системі, ускладнюючи перебіг інфекційного процесу в організмі. Цілком зрозуміло, що імунокорегуюча те- 
Огляди літератури, оригінальні дослідження, погляд на проблему, ювілеї

рапія, направлена на клітинну ланку імунної системи, відповідальної за процеси апоптозу, матиме, очевидно, успіх і впливатиме на збільшення запліднювальнго потенціалу. 3 цією метою ми вирішили дослідити вплив нуклексу на рівні активаційних маркерів у спермі інфертильних чоловіків із хронічним запаленням урогенітального тракту.

Нуклекс - сучасний імуноактивний препарат з дріжджової РНК. Основними фармакологічними ефектами препарату є стимуляція процесів клітинного метаболізму, посилення біосинтезу ендогенних нуклеїнових кислот, специфічних ферментів і протеїнів, посилення мітотичної активності клітин кісткового мозку, пришвидшення процесів регенерації, підвищення енергозабезпечення клітин шляхом стимуляції синтезу макроергічних сполук, таких як АТФ. Для виробництва нуклексу використовується субстанція гомогенної дріжджової РНК, яка має молекулярну вагу 7000 D та складається 3 23-25 нуклеотидів, що характерно для мРНК. За рахунок зміни просторової структури РНК субстанції поліпшено вже відомі її функціональні ознаки, що надало препарату нові властивості. Вона стимулює міграцію стовбурових клітин кісткового мозку, має протизапальну дію, нормалізує NO-синтетазну активність тощо. Загалом активність нуклексу пов'язана з імунокорегуючою дією препаратів нуклеїнових кислот.

Мета - дослідження маркерів активації лімфоцитів сперми чоловіків з малосимптомними формами хронічної інфекції урогенітального тракту в залежності від фертильності та впливу нуклексу на їх рівні.

Матеріал і методи дослідження. Було досліджено сперму 60 чоловіків, хворих на малосимптомні форми хронічного запалення урогенітального тракту (ХЗУТ); І групу склали 32 пацієнти, в яких діагностували ускладнення - інфертильність, у II групу ввійшли 28 фертильних пацієнтів.

Усіх пацієнтів обстежували клінічно, включаючи огляд та пальпацію статевого члена, мошонки та передміхурової залози, а також ретельно збирали анамнез. Усі пацієнти здавали сперму для аналізу. Напередодні здачі аналізу не повинно було відбуватися еякуляції упродовж 4-5 днів. Аналіз сперми проводили через півгодини після еякуляції та згідно з інструкцією ВООЗ. Враховували концентрацію сперматозоїдів, pH сім'яної рідини, вміст лейкоцитів та їх популяцій (гранулоцити, макрофаги, лімфоцити). Для визначення морфології використовували фарбування за Папаніколау.

Критерієм відбору пацієнтів у дослідження була відсутність запальної лейкоцитарної реакції та патологічної мікрофлори в сечовидільному ка- налі, секреті передміхурової залози, в секреті сім'яників та в спермі. Тривалість безпліддя становила 3-6 років. Вік обстежених складав 24-40 років. На початок обстеження минуло більше року після завершення попереднього лікування.

В анамнезі всі пацієнти перенесли інфекції, що передаються статевим шляхом (хламідії, уреаплазми, мікоплазми, герпесвірусна інфекція I/II типу), від 1 до 6 років тому, результати клініко-лабораторного видужання були підтверджені бактеріоскопічним, бактеріологічним, культуральним та плР-методами.

Для визначення рівня лімфоцитів, які на своїй поверхні експресують рецептори функціональної активації клітин CD4+CD25+, CD4+CD95+, CD4+HLA-DR4+ (TRAIL-рецептор 1), використовували еритроцитарний діагностикум з моноклональними антитілами виробництва НВЦ «МедБиоСпектр» (РФ, Москва). Для контролю імунологічних показників обстежено 15 практично здорових осіб, їх дані було прийнято за норму.

Результати й обговорення. В ході дослідження було виявлено, що перебіг малосимптомних форм ХЗУТ супроводжується зміною ряду показників імунної системи, порівняно з практично здоровими чоловіками.

У хворих на ХЗУТ, ускладнені безпліддям, спостерігався достовірно підвищений рівень CD4+CD25+ у спермі, як у відносних, так і в абсолютних значеннях, і склав $(16,8 \pm 1,4) \%((10,5 \pm 1,3) \%$ в контрольній групі) ( $<<0,01)$, що свідчить про посилену активність протиінфекційного захисту.

Рівень лімфоцитів у спермі з експресією CD4+CD95+ в I групі був підвищений, порівняно 3 контрольною групою, як у відносних, так і в абсолютних значеннях, і склав $(17,3 \pm 1,3) \%((12,6 \pm 1,3) \%$ у контрольній групі) ( $<<0,01)$. Кратність різниці склала 1,4 раза. Водночас, у частини хворих I групи (14 осіб) рівень CD4+CD95+ у спермі, навпаки, зменшувався відносно контролю, й середнє його значення у цієі частини хворих склало $(9,5 \pm 1,9) \%$ $(P<0,05)$, що було менше у 1,3 раза від прийнятої норми. Знижений рівень імунокомпетентних клітин, готових до вступу в процес апоптозу, може призводити до дисбалансу в імунній системі. Про активацію протиінфекційного захисту свідчить тенденція до збільшення абсолютного рівня клітин з експресією CD4+HLA-DR4+ у цій групі хворих.

У II групі хворих (фертильні чоловіки) рівні CD4+CD25+, CD4+HLA-DR4+ як у відносних, так і в абсолютних значеннях хоч і мали тенденцію до підвищення, але достовірно не відрізнялися від рівнів контрольної групи. Рівень лімфоцитів з експресією CD4+CD95+ маркера був підвищений, порівняно з контрольною групою, і склав $(26,3 \pm 1,7) \%$

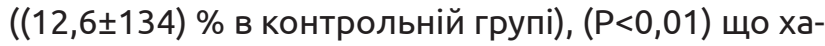


Огляди літератури, оригінальні дослідження, погляд на проблему, ювілеї

рактеризує підвищення кількості лімфоцитів, готових до апоптозу. Кратність різниці склала 2,1 раза.

Проведені нами дослідження ранніх (CD25+) та пізніх (CD95+ і HLA-DR4+) маркерів функціональної активації лімфоцитів у інфертильних та фертильних чоловіків з ХЗУТ виявили достовірне збільшення кількості лімфоцитів з рецептором CD25+ у хворих з безпліддям, тоді як у фертильних хворих спостерігали лише тенденцію до їх збільшення. Збільшення числа клітин з рецепторами до інтерлейкіну-2 (CD25+) пов'язане з активацією імунної системи під час відповіді на антиген при інфекції в урогенітальному тракті. У хворих обох груп спостерігали збільшення в спермі числа лімфоцитів, які несуть на своїй поверхні CD95-антиген, що характеризує активність процесів індукції апоптозу лімфоцитів в умовах вираженої стимуляції імунної системи при ХЗУТ. Але у безплідних чоловіків спостерігається не таке значне збільшення кількості лімфоцитів з експресією CD95+ маркера, порівняно з фертильними чоловіками (кратність різниці 1,4 проти 2,1 відповідно), а у частини хворих, навпаки, відбувалося достовірне зменшення експресії CD95+, що може вказувати на розвиток патоспермії. На підставі аналізу літературних даних ми обчислювали відношення CD25+/CD95+. Дослідження показало, що існує позитивний кореляційний зв'язок між підвищеним значенням пропорції CD25+/CD95+ та наявністю гіперголівчастих сперматозоїдів. Водночас збільшення цього індексу спостерігалося у групі інфертильних чоловіків. Достовірне зменшення пропорції CD25+/CD95+ спостерігалося у групі фертильних чоловіків, спермометрія в яких встановила переважання нормосоматичних форм сперміїв. Отримані дані свідчать, на наш погляд, про токсичну дію активованих лімфоцитів у спермі на тлі пригнічення процесів апоптозу.

Для вивчення впливу імунокорекції на маркери функціональної активності лімфоцитів у інфертильних чоловіків із хронічною формою запалення урогенітального тракту ми призначали ну- клекс у дозі 500 мг тричі на добу впродовж 30 днів поспіль (основна група - 18 чоловіків). Група контролю (19 чоловіків) отримувала базисну терапію. Обидві групи характеризувалися однотипними зсувами пропорції лейкоцитів та рівнями CD4+CD25+, CD4+CD95+, CD4+HLA-DR4+ у сироватці сперми інфертильних чоловіків. Після проведеного лікування обстеження обох груп хворих встановило зниження рівнів активаційних маркерів лімфоцитів. Проте у групі контролю ці рівні мали лише тенденцію до нормалізації й достовірно відрізнялися від нормативних. Рівні CD4+CD25+, CD4+CD95+, CD4+HLA-DR4+ у спермі безплідних чоловіків, які отримували нуклекс, вірогідно не відрізнялися від норми, на противагу групі хворих, які не отримували цей препарат. Таким чином, нуклекс, активуючи швидкість утворення і диференціювання лімфоцитів, інтенсивність апоптозу, приводить до нормалізації рівнів активаційних маркерів лімфоцитів. Про це свідчить не тільки зменшення рівнів CD4+CD25+, CD4+CD95+, CD4+HLA-DR4+ у спермі інфертильних чоловіків, а й нормалізація морфометричних властивостей сперміїв. Зменшення значення співвідношення CD25+/CD95+ у пацієнтів основної групи супроводжувалося зниженням кількості патологічних форм сперматозоїдів.

Висновки. 1. Вивчення маркерів активації лімфоцитів сперми у чоловіків, хворих на малосимптомні форми хронічної інфекції урогенітального тракту, вказує на різнопланові збільшення їх кількості залежно від фертильності.

2. Діагностично важливим $\epsilon$ визначення співвідношення CD25+/CD95+ для прогнозування розвитку інфертильності. Збільшення цього індексу вказує на порушення процесів апоптозу патологічних форм генеративних клітин, що призводить до їх накопичення у спермі.

3. Імунокорегуюча терапія з використанням нуклексу приводить до нормалізації співвідношення CD25+/CD95+, до зменшення патологічних форм сперматозоїдів й, зрештою, до збільшення запліднювального потенціалу.

\title{
ИЗУЧЕНИЕ ДИНАМИКИ УРОВНЕЙ СD4+ СD25+, CD4+ HLA-DR4+ И CD4+ CD95+ ЛИМФОЦИТОВ СПЕРМЫ ИНФЕРТИЛЬНИХ МУЖЧИН С ХРОНИЧЕСКИМ ВОСПАЛЕНИЕМ УРОГЕНИТАЛЬНОГО ТРАКТА ПОД ВЛИЯНИЕМ НУКЛЕКСА
}

\author{
๑С. Ю. Ципоренко, Л. Ф. Матюха \\ Национальная медицинская академия последипломного образования имени П. Л. Шупика \\ РЕЗЮМЕ. Введение. В практике семейных врачей участились случаи обращений мужчин с нарушением \\ оплодотворяющей функции. Тщательный сбор анамнеза позволяет заподозрить, что снижение фертильности у \\ мужчин сопровождается латентным и персистирующим течением урогенитальных инфекций, что очень \\ затрудняет их своевременную диагностику.
}


Огляди літератури, оригінальні дослідження, погляд на проблему, ювілеї

Цель - исследование маркеров активации лимфоцитов спермы мужчин с малосимптомными формами хронической инфекции урогенитального тракта в зависимости от фертильности и влияния нуклекса на их уровень.

Материал и методы. Была исследована сперма 60 мужчин, больных малосимптомными формами хронического воспаления урогенитального тракта (ХЗУТ). I группу составили 32 пациента, у которых диагностировали осложнения - инфертильность, во II группу вошли 28 фертильных пациентов.

Выводы. 1. Изучение маркеров активации лимфоцитов спермы у мужчин, больных малосимптомными формами хронической инфекции урогенитального тракта, указывает на разноплановое увеличение их количества в зависимости от фертильности.

2. Диагностически важным является определение соотношения CD25 + / CD95 + для прогнозирования развития инфертильности. Увеличение этого индекса указывает на нарушение процессов апоптоза патологических форм генеративных клеток, что приводит к их накоплению в сперме.

3. Иммунокорректирующая терапия с использованием нуклекса приводит к нормализации соотношения CD25+/CD95+, к уменьшению патологических форм сперматозоидов и, наконец, к увеличению оплодотворяющего потенциала.

КЛЮчЕВЫЕ СЛОВА: мужское бесплодие; сперма; маркеры активации лимфоцитов; иммунокоррекция; нуклекс.

\section{STUDY OF DYNAMICS OF CD4+ CD25+, CD4+ HLA-DR4+ AND CD4+CD95+ LEVELS OF SPERM LYMPHOCYTES IN INFERTILE MEN WITH CHRONIC INFLAMMATION OF UROGENITAL TRACT WITH INFLUENCE OF NUCLEUS}

\section{P. Shupyk National Medical Academy of Postgraduate Education}

\section{@)S. Yu. Tsiporenko, L. F. Matyukha}

SUMMARY. Introduction. In the practice of family doctors cases of male appetite with a violation of the fertilizing function have become more frequent. A careful collection of history suggests that reducing fertility in men is accompanied by a latent and persistent flow of urogenital infections, which makes it difficult to timely diagnose them.

The aim - to investigate the activation markers of sperm lymphocytes in males with asymptomatic forms of chronic infection of the urogenital tract, depending on the fertility and the effect of the nucleus on their level.

Material and Methods. The study was conducted on sperm of 60 men suffering from malosymptomatic forms of chronic inflammation of the urogenital tract (CIUT); And the group I consisted of 32 patients, in whom complications were diagnosed - infertility, group II included 28 fertile patients.

Conclusions. 1 . Study of the markers of activation of lymphocytes of sperm in men suffering from low-asymptomatic forms of chronic infection of the urogenital tract, indicates a diverse increase in their number depending on fertility.

2. Diagnostically important is the determination of the ratio of CD25+/CD95+ to predict the development of infertility. The increase of this index indicates the violation of the processes of apoptosis of pathological forms of the generative cells, which leads to their accumulation in the semen.

3. Immunocorrection therapy using the nucleus leads to the normalization of the ratio of CD25+/CD95+, to the reduction of pathological forms of sperm and, ultimately, to increase the fertility potential.

KEY WORDS: male infertility; sperm; lymphocyte activation markers; immunocorrection; nucleus.

Отримано 23.12.2018 